\title{
頭部外傷後緊張性気脳症
}

笑気麻酔による合併損傷手術後に発症した 1 例

定光 大海・澤田 祐介・西出 和幸·吉岡 敏治·杉本伿·越野兼太郎*

\section{Tension Pneumocephalus after Head Injury Associated with Nitrous Oxide Anesthesia for Extracranial Operation}

\author{
Case Report
}

\author{
Daikai Sadamitsu, Yusuke Sawada, Kazuyuki Nishide, Toshiharu Yoshioka, \\ Tsuyoshi Sugimoto and Kentaro Koshino* \\ Departments of Traumatology and ${ }^{*}$ Neurosurgery, Osaka University, Osaka
}

\begin{abstract}
A case of tension pneumocephalus associated with the use of nitrous oxide as an anesthetic agent for surgery is reported.

The patient was a 30-year-old male, admitted with multiple injuries caused by a traffic accident. On admission, his consciousness was slightly disturbed but no other neurological deficits were assessed. The computerized tomography (CT) scan revealed a small amount of air in the frontal subdural and intracerebral spaces. A skull X-ray showed a short linear fracture on the frontal bone. A basal skull fracture was suspected by clinical findings but was not comfirmed by X-ray examination. Six hours after an operation for open fractures of tibia and fibra under general anesthesia with $66 \%$ nitrous oxide, neurological deficits suddenly occurred. A CT scan and a skull X-ray showed a marked increase in the size of the subdural air. Twelve hours later, the air diminished according to a follow-up X-ray and the neurological deficits gradually decreased spontancously. A CT scan on the 4th hospital day showed no intracranial air collection.

In this case the use of nitrous oxide was suspected to play an important role in the genesis of tension pneumocephalus. It was concluded that the use of nitrous oxide should be avoided in the cases of multiple injuries with basal skull fractures.
\end{abstract}

Key words: tension pneumocephalus, nitrous oxide, anesthesia

\section{I はじめに}

頭部外傷早期に頭蓋內空気の著明な增量に上り頭蓋內厅: 六進症状を呈するいわゆる tension pneumocephalus (以下 TP)はきわわてまれであり，その報告例も散見するのみで ある，我々は，頭蓋底骨折を伴った多発外傷例で，頭蓋内
になんら手術操作を加えていないにもかかわらず合併摃傷 手術後に TP を発症した 1 例を経験した。本稿では，本䤠 TP の発生機序解明のため文献的考察を加え，本例のごと く多発外傷で頙蓋底骨折を伴った例では合併損傷手術に際 し笑気ガスが TP 発症の䖪い要内となりうることを明らか にしたので報告する。

\section{大阪大学特殊救急部 *同兴神释外科}

Address reprint requests to: D. Sadamitsu, M.D., Department of Traumatology, Osaka University, 1-1-50 Fukushima, Fukushima-ku, Osaka 553.

受稿 1983 年 8 月19日受理 1984 年 2 月 9 月 


\section{II 症例}

<患者> 30 才, 男性

主訴：党部障害

家族歴・既往歴：特記すべきことなし

現病歴：1981年10月22日，ミニバイクを腌転中普诵乗用

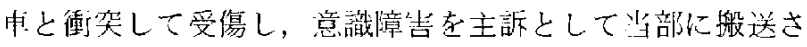
机た。

来院時斥見：意膱混濁，血圧 $170 / 90 \mathrm{mmHg}$ ，脈拍 $120 /$ $\mathrm{min}$, 呼吸数 $28 / \mathrm{min}$ で女り，鼻出血，石前頭部擦過傷㧍 よび存卜腿骨開㸡性骨折が歹られた。胸・腹部に理学的異 常所見はみられなかった。视経学的所見としてはGlasgow Coma Scale (GCS)にて Score $9\left(\mathrm{E}_{1} \mathrm{~V}_{3} \mathrm{M}_{5}\right)$ の意裁レベル低 ドを認めたのみであり，その他の脳神経系，連動・知覚神 経系に買常はみられなかった。

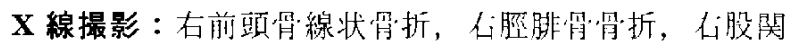
節脱臼骨折，骨盤骨折がみられた。

CT scan：硬膜下腔扣よび脳実算从に少早の空気像在認 めたが，明らかな血腫や脳挫傷はみられなかった（Fig. 1).

米院㙮神経学的泟状の墇悪がみられないため，まず企身 麻酔卜で石卜腿骨開放性骨折㧍よび石股関節脱以骨折の観 血的整復術を施行した。林酔はGO-NLA で $\mathrm{N}_{2} \mathrm{O} 66 \%$ に維 持し, 千術時間は 5 時間10分であった。な拉，術前に気管 内挿管操作を 3 度繰り这し行っている。術直得神経的異 常所昌はみら机なかったが，術後6 時間経過した時点で突 然曈孔不同(右 $2.0 \mathrm{~mm} \phi$, 左 $2.5 \mathrm{~mm} \phi)$ が出現し，対光反射 む左で微弱になり，さらにGCSにて Score 6 と意龍レべ ル低下む忍めたため，皘発性外伤性脳内向腫の発生を是

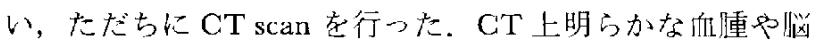
浮腫像は唸められなかったが，前䪽部硬膜下空に異常なが

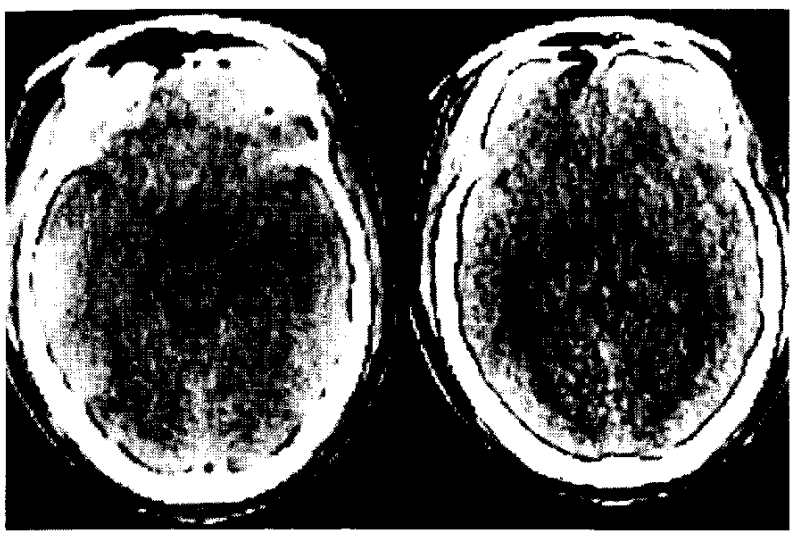

Fig. 1 CT scans showing air in the frontal subdural and intracerebral spaces.

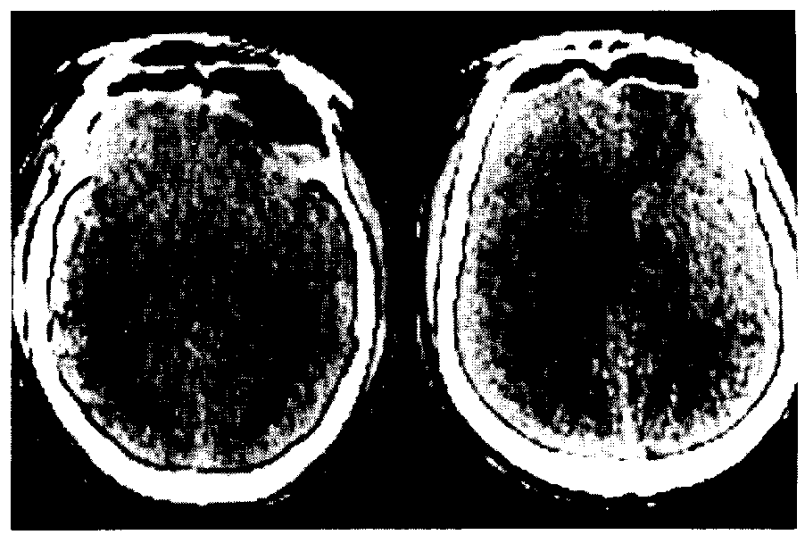

Fig. 2 CT scans showing a marked increase in the amount of the subdural air

ス貯留像がみられた(Fig. 2)。そこで，機械的人工呼吸下 に神経学的㾚状の变化と䫓部 X 線側而写上での頭篮内空 気の変化を経過観察したが，意載レバルの低下や他の神経 学的所見の增悪もなく， vital signに変化はみられなか った。ささらに12時間経過したのちには意諸レベルの改善が みられ，䫓部X線側面写にて女頭蓋内空気像は減少倾向 を示した，来㫟時，極期，軽快期のX線側晌像老 Fig. 3 に示す。

24時問後，再度全身麻酷下にて骨盤骨折の街血的整復術 を施行した。麻酔は oxygen-ethraneで維持，笑安注使用 せず，全手術時間は6 時間であった。術㣪経過は問題な く，第 3 病日には意識もほぼ清明となり，第 4 病Hには気 管内挿管チューブも抜管しえた，CT上頭盖内空気像は消 坐し(Fig，4)，朣孔不同も消失した。第 6 将H上り細菌性 揈膜炎を併発したが，抗生物質投与にてしだいに改善し， 第15病日には軽快軾医した。

\section{III 考察}

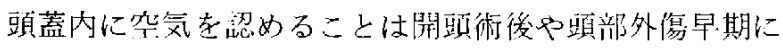
しばしばあるが，それ自体が臨床症状を引き起こすことは きわめてまれである。“Tension pneumocephalus”とは顛 蓋內公気自体が頭盖内压元進を哥さ起こしさまざまな神経 证状を呈するものと定義される闹ものの，乙の発生機序 はいまだイ明の尔を残している。

1982年までの過去10年間に TP として報先された例は43 例になる。これらに共通した概念は“intracranial air accumulation under pressure”であり，頭莣风压に逆らって 空気が韻蓋內に集積する機序についてさまざまな考察がな されている，頭盖内に䆑気が侵人する機序としては，開頭 術による大気への曝露やや髄液ドレナージに伴う空気と娟 


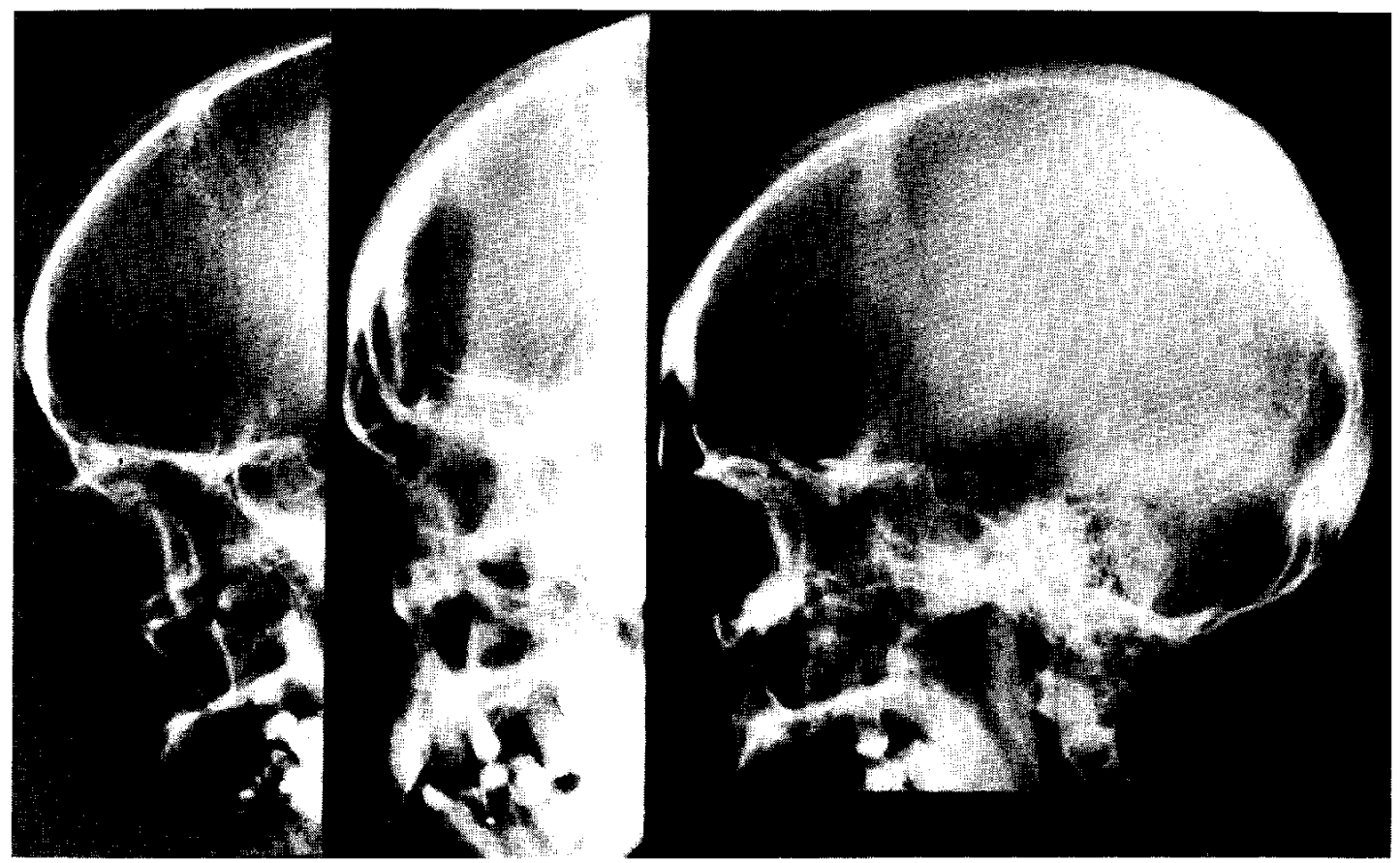

Fig. 3 Lateral views of the skull X-ray showing changes in the air. left: On admission, a small amount of air is seen in the frontal region. center: Six hours after operation, the air is markedly increased. right: Twclve hours after operation, the air is considerably diminished.

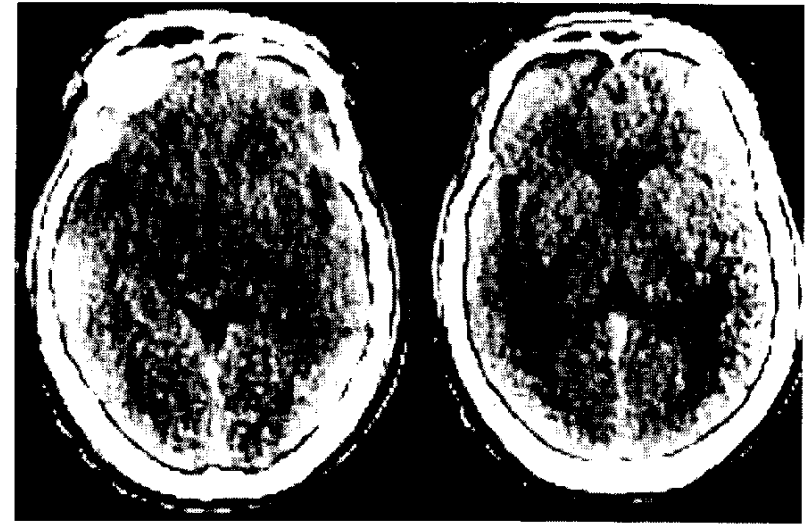

Fig. 4 CT scans 4 days after operation, showing no intracranial air collections

液の置換う，碩蓋底骨折など頭蓋内外の交通している郘分 からの空気侵入10.12) が指摘され，これらが頭荒内圧に逆ら ってその容皘を増大させる機序としては，(1)侵入した空気

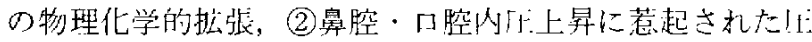
勾配に基つく顽蓋内一の持続的な帘気の流入の2つが想定 されている。(1)は吸人柘醉剂である笑気による置换?や大 気上頭蓋内の温度差による侵大空気の膨張"'が主な原肉で あり，(2)としてはsneczc, cough, straining，あるいは気管内 插管操作が引金になると考えられている10 .

自験例の TP 発生機惊解明を日的乞して本拉報告例の5 ち詳細の明らかな29例在対缘に挨討在加えてみると，原因 となる手術操作あるいは疾患に上り TP 発生時期に大きな 差があり(Fig. 5)，この発特時期之のものが発牛機序々密 接な関係にあることが判った。 Sitting positionによる開頭 手術例では術直後から数時間以内のきわめて古期に全例発

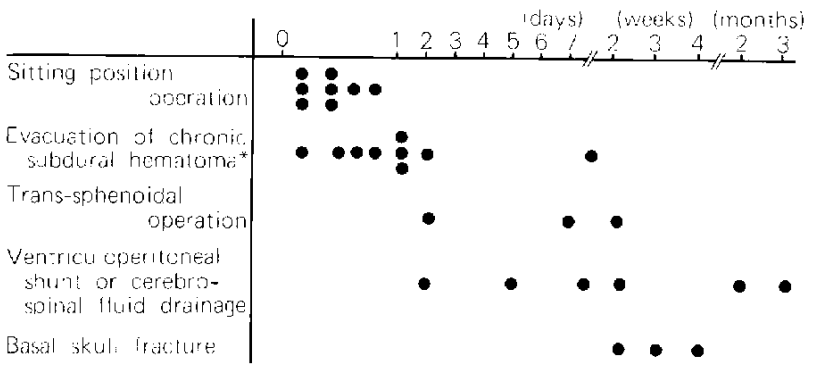

Fig. 5 Elapsed time before the rension pneumocephalus with fulminant neurological symptoms appeared in 29 previously reported cases. *4 cases underwent a burr holing procedure and 5 cases decompressive cranicctomy. 
症しており，いずれも術中麻酔剤として笑気を使用してい るため TP発現の主琶因は笑気であり，頭盖内に残存した 空気上笑気の置換に上る容棈の增大が本症老若起したと考 えられる

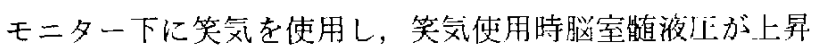
することを証明している，慢性硬膜下血腫手術例では2例 除きすべて48時間以内に無症しているが，笑気使用例は 3 例でいずれも24時間経過後発症してお゙り，TP発現に対

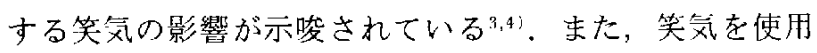
していない例ではいずれも術中挿入されたドレーン抜吉後

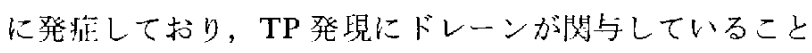
は確かであるが，その発生機宁はなお不明の点を残してい る. Bouzarth $5^{3}$ は，頭蓋内外の温度差による流入空気の 膨脹がTP起こし5ると説明している。一方他の㪕告例 は，原因の差こそあれいずれも頭莣底で頭盖内外に交通が ある症例で，発症までの時間も長いことが特徽である。前 述した(2)の機序がこれら症例のTP発生機序として説明さ れているが, cough, sneeze, strainingなとに若起された頭 盖内人の空気の蓄積が TP 発現するにはかなりの时間を 荘することを示している。

これらの㛟訪を踏まえて自験例を解析してみると，目験 例の特徴は，外傷例で臨床所見から頭蓋底骨折が示唆され ること，䫓部に手術操作は加わっていないこと，他部位の 合併損傷手術後 6 時間とい5きわ力て早期に発疪している こと，吸入麻酔剤として笑気を使用していること，症状発 現が一過性であることの5点にあり，TP発生機序の主要 团が笑気であることは疑いない上苊えられる，笑氮と置換 された頭蓋内空気は，受傷時执よび繰り返された插管操作 時に冎折部加ら直接侵入したるの上思われる。本例は磌蓋 底骨折を伴った多発外傷で頙荒内になんら子術操作を加え ていないにもかかかららず発特している点が特幑であり，こ のことは，多発外傷で頭蓋底骨折を伴った場合䫓部以外の 合併損傷手術でも麻酔剂としての笑気使用が本拝を若起す る可能性があることを示している。したがのて，多発外傷

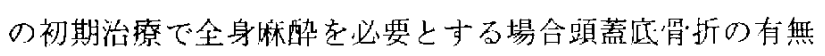
在確認することが大切であり，その存在が疑われたときは 暴力的な挿管操作や麻酔剂である笑気が本怔を芯起する叮

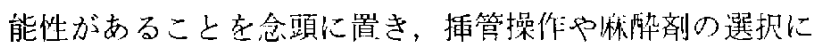
十分配雭する必要がある。

本症の治療よしては手術による䫓蓋内空気の除去が安全 かつ確実な方法であり，報告された泣例のほとんどがこれ に上り劇的な拝状の改善示している。然吸收索期待し た保存療法は，本剂のごとく全身麻酔下の乎術徭24時間以 内に発症し明らかに笑気が原因上考えられる症例に限るべ きであろう。しかしこのような症例であっても慎重な経逈
観察が必要であり，臨床症状の増禹や頭盖内空気の増大傾 向を示寸例ではいたずらな経過観察は迬け，千術療法を選 択すべきと考える。机，頙蓄内に空気が存在することは その原因がなんであれ細菊性蹎膜炎を続発する伦険性在有 することにほかならず，感染対策も同時に忘れてはならな い問題と忈える.

\section{IV 結 語}

1. 頙蓋底骨折を伴った多発外傷で，頭盍内になんら手 術操作を加えていないにもかか力らす合併損傷手術徭早期 に発症した tension pneumocephalus の1 例を経駿した。

2. 本例に打ける発泟の主要因が吸入林舅剂として使用 した笑気がスであることを，文献的考察も加えて明らかに Lた.

3. 多発外傷例で全身麻酔が必要な場合頭蓋诋骨折の有 無の確訫が必要であり, その存在が疑われたときは㨂管操 作や麻酔剂の選択に十分な配虑が必要である上結論でき t.

\section{文献}

1) Artru AA: Nitrous oxide plays a direct role in the development of tension pneumocephalus intraoperatively. Anesthesiology 57: 5961, 1982

2) Black PM, Davis JM, Kjellberg RN, Davis KR: 'l'ension pneumocephalus of the cranial subdural space: A case report. Neurosurgery 5: 368-370, 1979

3) Bouzarth WF, Hash CJ, Lindermuth JR: Tension pneumocephalus following surgery for subdural hematoma. J Trauma 20: 460-463, 1980

4) Bremer AM, Nguyen TQ: Tension pneumocephalus after surgical treatment of chronic subdural hematoma: Report of three cases. Neurosurgery 11:284-287, 1982

5) Effron MZ, Black FO: Tension pneumocephalus complicating the treatment of postoperative CSF otorrhea. Arch Otolaryngol 107 : $579-580,1981$

6) Friedman GA, Norfleet EA, Bedford RF: Discontinuance of nitrous oxidc docs not prevent tension pneumocephalus. Anesth Analg (Cleve) 60: 57-58, 1981

7) Kitahara LM, Katz JD: Tension pneumocephalus after posterior-fossa craniotomy, a complication of the sitting position. Anesthesiology 44: 448-450, 1976

8) Leunda G, Cabezudo JM, Areitio F, Vaquero J, Gilsanz F: Subdural tension pncumoccphalus after posterior fossa operation: Is the inverted bottle phenomenon the only causative factor? Surg Neurol 15: 303-305, 1980

9) Lunsford LD, Maroon JC, Sheptac PE, Albin MS: Subdural tension pneumocephalus, report of two cases. $J$ Neurosurg 50 : 525527,1979

10) Magnaes B, Nornes $H$ : Traumatic tension pneumo- 
hydrocephalus. Acta Neurochir (Wien) 27: 17-27, 1972

11) Thiagarajah $S$, Frost EAM, Singh $T$, Shulman K: Cardiac arrest associated with tension pneumocephalus. Anesthesiology 56 : 73-75, 1982

12) Wesley RE, McCord CD: Tension pneumocephalus from orbital roof fracture. Ann Ophthalmol 14: 184-190, 1982

〔別刷請求先 : $\mathbf{\mathbf { T }} 553$ 大阪市福島区福島 1-1-50, 大阪大学特殊 救急部, 定光大海] 